\title{
Agronomic Evaluation of the Results of Selection within Early Maturing Dactylis glomerata Germplasm
}

\author{
Joseph G. Robins* ${ }^{\mathbb{D}}$, B. Shaun Bushman and Kevin B. Jensen \\ USDA Forage and Range Research Laboratory, Logan, UT 84322, USA; shaun.bushman@usda.gov (B.S.B.); \\ kevin.jensen@usda.gov (K.B.J.) \\ * Correspondence: joseph.robins@usda.gov; Tel.: +1-435-999-9041
}

\begin{abstract}
Selection from novel orchardgrass (Dactylis glomerata L.) germplasm sources resulted in the development of an early maturing orchardgrass population. Fifty-eight families comprise this population and were evaluated under frequent and infrequent harvest intervals at Lewiston and Millville, UT, field locations during 2013 and 2014. The objective of this study was to characterize the performance of the individual families when compared with the check cultivars 'Icon', 'Paiute', and 'Potomac'. Across the locations and harvest intervals, individual families produced greater herbage dry mass and nutritive value than the check cultivars. Only for maturity (cv. Paiute) did one of the included commercial checks possess a trait value among the statistically greatest for all families. Twenty-two half-sib families were among the families with the statistically earliest maturity, and between three and eight families were among the families with the statistically greatest trait values for herbage dry mass, crude protein, in vitro true digestibility, neutral detergent fiber, and water soluble carbohydrate concentration. Overall, based on the performance of its component families, this early maturing orchardgrass population exhibited potential for developing improved cultivars for both frequent and infrequent harvest management.
\end{abstract}

Citation: Robins, J.G.; Bushman, B.S.; Jensen, K.B. Agronomic Evaluation of the Results of Selection within Early Maturing Dactylis glomerata Germplasm. Agronomy 2021, 11, 1505. https://doi.org/10.3390/ agronomy11081505

Academic Editor: Daniel Real

Received: 25 May 2021

Accepted: 26 July 2021

Published: 29 July 2021

Publisher's Note: MDPI stays neutral with regard to jurisdictional claims in published maps and institutional affiliations.

Copyright: (C) 2021 by the authors. Licensee MDPI, Basel, Switzerland. This article is an open access article distributed under the terms and conditions of the Creative Commons Attribution (CC BY) license (https:/ / creativecommons.org/licenses/by/ $4.0 /)$.

Keywords: biomass; cocksfoot; grazing; hay; herbage; nutritive value; orchardgrass

\section{Introduction}

Orchardgrass (Dactylis glomerata L.) is an important perennial cool-season grass for livestock production in temperate regions. Orchardgrass usage includes hay, ensiling, and grazing, and orchardgrass production frequently includes mixtures with other perennial grasses or legumes, such as alfalfa (Medicago sativa L.) [1]. Its use is limited by lower forage quality than perennial ryegrass (Lolium perenne L.) and lower stress resistance than tall fescue (Lolium arundinaceum (Schreb.) Darbysh.) [2,3]. Orchardgrass is divided into early, intermediate, or late maturing cultivar classes. Early maturing cultivars of orchardgrass are valued for hay management because they often produce more dry matter than later maturing cultivars [4]. Early maturing cultivars also mix well with white clover (Trifolium repens L.) but not later maturing legumes, such as alfalfa or birdsfoot trefoil (Lotus corniculatus L.) (reviewed in [5]).

Orchardgrass breeding efforts are ongoing to develop improved cultivars that possess high production potential in different management systems and for the different maturity classes. The evaluation of genetic gains achieved from orchardgrass breeding under hay management found that, over time, orchardgrass forage yield and ground cover increased only in the early maturing class and that most commercial cultivars are not an improvement compared with previously released cultivars [6]. While gains occurred in early maturing orchardgrass for hay management, there were not similar gains for grazing management [7]. Subsequent research identified high levels of genetic variation within novel sources of orchardgrass germplasm [8-10] and documented gains in the forage yield under hay management [11]. Thus, the use of novel sources of orchardgrass germplasm is a potential method to overcome stagnant yields in this species. 
This study documents the performance of 58 families from a broad-based early maturing orchardgrass population that was itself derived from seven germplasm sources. The 58 families were evaluated for herbage dry mass (HDM), maturity (MAT), and nutritive value at two northern Utah field sites differing in soil characteristics under both frequent and infrequent harvest interval schedules.

\section{Materials and Methods}

\subsection{Half-Sib Families}

In 2011, open-pollinated seed was harvested from 58 plants originating from seven orchardgrass germplasm sources (Table 1). The seven orchardgrass germplasms were IADG103, IADG104, IADG105, Latar-Select, Paiute-Select, Potomac-Select, and UTDG102.

Table 1. Dactylis glomerata half-sib family source populations, including the number $(\mathrm{N})$ of families corresponding to each population; and cultivars.

\begin{tabular}{clcc}
\hline Family & Type & N & Source \\
\hline IADG103 (I3) & Half-sib families & 4 & {$[8]$} \\
IADG104 (I4) & Half-sib families & 2 & {$[8]$} \\
IADG105 (I5) & Half-sib families & 7 & {$[8]$} \\
Latar-Select (LaS) & Half-sib families & 15 & {$[8]$} \\
Paiute-Select (PaS) & Half-sib families & 13 & {$[8]$} \\
Potomac-Select (PoS) & Half-sib families & 15 & {$[8]$} \\
UTDG102 (U2) & Half-sib families & 2 & {$[8]$} \\
cv. Icon (In) & Cultivar & 1 & DLF Pickseed North America \\
cv. Paiute (La) & Cultivar & 1 & {$[12]$} \\
cv. Potomac (Po) & Cultivar & 1 & {$[12]$} \\
\hline
\end{tabular}

\subsection{Experimental Locations and Establishment}

Using the open-pollenated seed, the plots were seeded at Lewiston and Millville, UT, in August 2012. The Lewiston field site is at $41.95^{\circ} \mathrm{N} 111.88^{\circ} \mathrm{W}$, is $1373 \mathrm{~m}$ above sea level, receives $472 \mathrm{~mm}$ annual precipitation, and has a Kidman and Lewiston fine sandy loam soil (coarse-loamy, mixed, superactive, mesic Calcic Haploxerolls). The Millville field site is at $41^{\circ} 41^{\prime} 52^{\prime \prime} \mathrm{N}, 111^{\circ} 49^{\prime} 53^{\prime \prime} \mathrm{W}$, is $1378 \mathrm{~m}$ above sea level, receives $432 \mathrm{~mm}$ annual precipitation, and has a Nibley silty clay loam soil (fine, mixed, mesic, Aquic Argiustolls). Treatments at both sites included plots managed under frequent (simulated grazing) and infrequent (simulated hay production) harvest intervals.

A cone seeder was used to seed the plots $(1 \mathrm{~m} \times 2 \mathrm{~m}$; five rows $0.25 \mathrm{~m}$ apart $)$ at a rate of 1 pure live seed per linear $\mathrm{cm}$. The plots were then uniformly irrigated to maintain a moist soil surface until seedling emergence. Irrigation was then applied at $\sim 30 \mathrm{~mm} \cdot \mathrm{wk}^{-1}$ through September 2012 to ensure adequate plant development prior to winter.

The experimental design for each site and harvest interval combination was an augmented design following a previously published approach [13]. The plant materials used were the 58 half-sib families and the commercial cultivars 'Icon', 'Paiute', and 'Potomac'. The plots at each site and harvest interval combination were arranged in eight incomplete blocks with the three commercial cultivars included in each incomplete block to compute experimental error, although a planting error at the Lewiston site resulted in some blocks containing only one of the commercial checks.

Fifty six kilograms of $\mathrm{N}$ fertilizer (31-0-0) ha ${ }^{-1}$ were applied to each plot annually, with three split applications at early spring, after the first harvest, and after the third harvest (frequent harvest) or second harvest (infrequent harvest). Irrigation was applied to each plot weekly at a rate equal to the weekly evapotranspiration amount.

A sickle-bar forage harvester was used to harvest the aboveground biomass from each plot to a stubble height of $100 \mathrm{~mm}$. The wet biomass was weighed with the harvester's onboard scale. The frequent harvest plots were harvested seven times at approximately 23-day intervals in 2013 and five times at approximately 31-day intervals in 2014. The difference 
in harvest numbers between the years was due to a mid-summer irrigation failure at the Lewiston location in 2014. The infrequent harvest plots were harvested four times at 42-day intervals in both 2013 and 2014. Approximately $300 \mathrm{~g}$ samples were hand-collected by collecting a representative sample from across each plot, weighing, and then drying in a forced air drier at $60{ }^{\circ} \mathrm{C}$ for three days. Following drying, the samples were reweighed and the ratio of the dry to wet weight was used to adjust the plot HDM values. These samples were subsequently ground to pass a $1 \mathrm{~mm}$ screen and scanned by near-infrared reflectance spectroscopy (NIRS) (Foss, Hilleroed, Denmark). NIRS scan values were then used to estimate the values of crude protein (CP), in vitro true digestibility (IVTD), neutral detergent fiber digestibility (NDFD), and water-soluble carbohydrate concentration (WSC) based on a percentage of dry matter. The equation used was the NIRS consortium equation 18gh50.eqa [14]. Maturity data were collected prior to first harvest, except for the frequent harvests in 2013, using a visual rating based on the number and extent of heads emerged from the leaf sheath (1-very late to 5-very early).

The data were analyzed as a multi-environment augmented design using the lme4 package [15] of the R statistical software [16]. Year, location, harvest frequency, family, and their interactions were fixed effects, and the model controlled for spatial variation [17]. Although the families were half-sib families because they arose from selection and because the interest was in their specific performance and not as representative samples of the population, they were considered a fixed effect. Incomplete block and year $\times$ incomplete block interaction were random effects. The emmeans package was used to estimate means for each factor [18]. The phenotypic correlations among traits were estimated using the cor.test command of $\mathrm{R}$.

\section{Results and Discussion}

\subsection{Overview}

This study characterized the performance of orchardgrass families derived from the intermating of several germplasm sources for their agronomic performance under frequent and infrequent harvest intervals. The families were selected from space-plant nurseries evaluated under a hay (infrequent) harvest interval for dry matter production and forage quality, among other traits [8,9]. As these families were selected from a space-plant evaluation, it was unclear what their performance would be in sward conditions because correlations between space-plant and sward evaluations are often low in perennial forage grasses [19-21]. Thus, it was necessary to evaluate these families under sward conditions and varying harvest intervals to verify their utility for further orchardgrass improvement.

\subsection{Year, Location, and Harvest Frequency Effects}

There were differences $(p<0.001)$ between the 2013 and 2014 years, between the Lewiston and Millville sites, and between the frequent and infrequent harvest intervals for HDM, CP, IVTD, NDFD, and WSC (Table 2). There were also differences between the 2013 and 2014 years and between the frequent and infrequent harvest intervals for MAT. The year $\times$ location, year $\times$ harvest interval, and year $\times$ location $\times$ harvest interval interactions differed from zero for all traits but MAT. The location $\times$ harvest interval interaction differed from zero for HDM, CP, and IVTD (Table 2). Despite the significance of the interactions with year, orchardgrass is a perennial species and must survive across multiple years. Thus, all results were averaged across the two production years and the corresponding year interaction effects were ignored [22]. 
Table 2. Mean trait values corresponding to the main effects of year, location, and harvest frequency. Traits were maturity (MAT; 1 - very late to 5-very early), herbage dry mass (HDM; $\mathrm{Mg} \mathrm{ha}^{-1}$ ), crude protein $\left(\mathrm{CP} ; \mathrm{g} \mathrm{kg}^{-1}\right)$, in vitro true digestibility (IVTD; $\mathrm{g} \mathrm{kg}^{-1}$ ), neutral detergent fiber digestibility (NDFD; $\mathrm{g} \mathrm{kg}^{-1}$ ), and water-soluble carbohydrates (WSC; $\mathrm{g} \mathrm{kg}^{-1}$ ) and were measured on 58 orchardgrass families and three commercial cultivars during 2013 and 2014 at Lewiston and Millville, UT, under frequent and infrequent harvest intervals. Values in the same column and for the same effect followed by different letters differ at least at the $5 \% \alpha$ level.

\begin{tabular}{|c|c|c|c|c|c|c|}
\hline Effect & MAT & HDM & $\mathrm{CP}$ & IVTD & NDFD & WSC \\
\hline \multicolumn{7}{|c|}{ Year } \\
\hline 2013 & $2.4^{\mathrm{b}}$ & $16.9^{b}$ & $176^{\mathrm{a}}$ & $835^{b}$ & $726^{a}$ & $49^{b}$ \\
\hline 2014 & $3.1^{\mathrm{a}}$ & $18.1^{\mathrm{a}}$ & $174^{\mathrm{b}}$ & $846^{\mathrm{a}}$ & $715^{b}$ & $65^{\mathrm{a}}$ \\
\hline \multicolumn{7}{|c|}{ Location } \\
\hline Lewiston & $2.8^{\mathrm{a}}$ & $21.8^{\mathrm{a}}$ & $165^{b}$ & $817^{\mathrm{b}}$ & $691^{b}$ & $54^{b}$ \\
\hline Millville & $2.8^{\mathrm{a}}$ & $13.2^{b}$ & $185^{\mathrm{a}}$ & $865^{a}$ & $750^{a}$ & $59^{a}$ \\
\hline \multicolumn{7}{|c|}{ Harvest Frequency } \\
\hline Frequent & $3.0^{\mathrm{a}}$ & $17.2^{\mathrm{b}}$ & $199^{a}$ & $863^{a}$ & $733^{a}$ & $58^{\mathrm{a}}$ \\
\hline Infrequent & $2.5^{b}$ & $17.8^{\mathrm{a}}$ & $151^{b}$ & $818^{\mathrm{b}}$ & $708^{b}$ & $56^{\mathrm{b}}$ \\
\hline \multicolumn{7}{|c|}{ Location $\times$ Harvest Frequency } \\
\hline Lewiston $\times$ Frequent & $2.6^{\mathrm{c}}$ & $20.7^{\mathrm{b}}$ & $200^{a}$ & $850^{c}$ & $703^{a}$ & $56^{\mathrm{a}}$ \\
\hline Lewiston $\times$ Infrequent & $2.9^{b}$ & $22.8^{a}$ & $130^{c}$ & $784^{\mathrm{d}}$ & $679^{a}$ & $53^{a}$ \\
\hline Millville $\times$ Frequent & $3.4^{\mathrm{a}}$ & $13.6^{\mathrm{c}}$ & $198^{a}$ & $876^{a}$ & $763^{a}$ & $61^{\mathrm{a}}$ \\
\hline Millville $\times$ Infrequent & $2.2^{\mathrm{d}}$ & $12.9^{\mathrm{d}}$ & $172^{b}$ & $853^{b}$ & $737^{a}$ & $58^{a}$ \\
\hline
\end{tabular}

As annual precipitation and temperatures were similar at the two sites during the study, large trait differences between the sites are due to soil differences. The Millville site rates lower than the Lewiston site for farmland suitability, irrigated capability, and irrigated crop ratings $[23,24]$. The sandier Lewiston location presumably allowed for greater root access to water than did the clay soils at the Millville site, which likely constricted root exploration and mining of the soil [25].

\subsection{Orchardgrass Family Effects}

There were wide differences $(p \leq 0.04)$ among the orchardgrass families for each trait (Table 3). The cultivar Paiute, one IADG104 family, two IADG105 families, five LatarSelect families, two Paiute-Select families, ten Potomac-Select families, and one UTDG102 family comprised the 22 families with the statistically earliest MAT scores (MAT $\geq 3.1$ ) (Table S1). The early maturing families derived from the cultivar Latar showed that even a late-maturing cultivar maintained substantial genetic variation and heterogeneity for this trait and was a potential source of germplasm for the development of early maturing populations [12,26]. 
Table 3. Summary of the experiment-wide mean values corresponding to 58 orchardgrass families and three commercial cultivars evaluated in 2013 and 2014 at Lewiston and Millville, UT, under frequent and infrequent harvest frequencies. High and low family values correspond to the families with the numerically highest and lowest trait values. Means are across years, location, and harvest frequencies. Traits are maturity (MAT; 1 -very late to 5-very early), herbage dry mass (HDM; Mg $\mathrm{ha}^{-1}$ ), crude protein $\left(\mathrm{CP} ; \mathrm{g} \mathrm{kg}^{-1}\right.$ ), in vitro true digestibility (IVTD; $\mathrm{g} \mathrm{kg}^{-1}$ ), neutral detergent fiber digestibility (NDFD; $\mathrm{g} \mathrm{kg}^{-1}$ ), and water soluble carbohydrate concentration (WSC; $\mathrm{g} \mathrm{kg}^{-1}$ ).

\begin{tabular}{ccccccc}
\hline & MAT & HDM & CP & IVTD & NDFD & WSC \\
\hline High Family & 3.7 & 20.1 & 190 & 852 & 761 & 68 \\
Low Family & 1.5 & 15.3 & 164 & 790 & 685 & 48 \\
Icon & 2.3 & 16.6 & 178 & 845 & 726 & 60 \\
Paiute & 3.2 & 16.9 & 177 & 840 & 723 & 54 \\
Potomac & 2.7 & 16.3 & 180 & 842 & 731 & 55 \\
Mean & 2.8 & 17.5 & 175 & 841 & 720 & 57 \\
Least Significant Difference 5\% & 0.8 & 1.6 & 9 & 7 & 23 & 7 \\
\hline
\end{tabular}

Eight, three, nine, six, and seven families were among the statistically highest groups for HDM, CP, IVTD, NDFD, and WSC, respectively (Table S1). Additionally, twelve families were among the statistically highest group for more than one trait (Table S1).

Despite the high performance of some families for multiple traits, there was little evidence for correlation among the traits. Only the correlation estimates for four trait combinations significantly differed from zero and those estimates were all low: CP and $\operatorname{IVTD}(\rho=0.47, p \leq 0.001), \mathrm{CP}$ and NDFD $(\rho=0.32, p<0.05), \operatorname{IVTD}$ and NDFD $(\rho=0.46, p$ $\leq 0.001)$, and IVTD and WSC $(\rho=0.33, p<0.05)$. The positive, although weak, correlations between the nutritive value traits were expected, but the usual negative correlations between HDM and nutritive value traits were not present in this study [27,28]. Whether this was due to the included genotypes, the choice of environments, or a combination of these factors is not clear.

In contrast with the sister study of late-maturing orchardgrass germplasm, the interactions between the early maturing families and locations or harvest intervals did not generally differ from zero [24]. The only instances of significant location $\times$ family or harvest $\times$ family interactions were for IVTD and WSC. The lack of interaction between families and harvest interval contradicted previous findings in orchardgrass that did not find an interaction between the genotype effect and defoliation methods [11]. The lack of interactions with the orchardgrass families eases selection decisions within this population, although additional evaluation in a wider collection of irrigated locations would be necessary to remove the effects of genotype $\times$ environment interactions from plant breeding decisions. However, at least preliminarily, the results of the evaluation suggest that these sites, which are good representations of other irrigated sites in the Intermountain area of the U.S., may be treated as one large macroenvironment for plant breeding [29]. This is consistent with the wide geographic adaptation used for commercial seed sales in the perennial forage seed market [30,31].

Overall, the results of this study indicate that selection within novel orchardgrass germplasm sources [8,9] has been successful at developing an elite early maturing population. Several individual families possess great potential for orchardgrass germplasm improvement. Specifically, the trait performance of several families was better than that of the included check cultivars. Additional selection within the population should result in the release of improved orchardgrass cultivars, although the ability to develop improved orchardgrass cultivars separately for hay and grazing management is limited by the ability of the seed market to support such releases.

Supplementary Materials: The following are available online at https:/ / www.mdpi.com/article/10 .3390 /agronomy11081505/s1, Table S1: Mean values corresponding to 58 orchardgrass families and three commercial cultivars evaluated in 2013 and 2014 at Lewiston and Millville, UT, under frequent 
and infrequent harvest frequencies. Means are across years, location, and harvest frequencies. Traits are maturity (MAT; 1 -very late to 5-very early), herbage dry mass (HDM; $\mathrm{Mg} \mathrm{ha}^{-1}$ ), crude protein $\left(\mathrm{CP} ; \mathrm{g} \mathrm{kg}^{-1}\right.$ ), in vitro true digestibility (IVTD; $\mathrm{g} \mathrm{kg}^{-1}$ ), neutral detergent fiber digestibility (NDFD; $\mathrm{g} \mathrm{kg}^{-1}$ ), and water soluble carbohydrate concentration (WSC; $\mathrm{g} \mathrm{kg}^{-1}$ ). Values in the statistically highest grouping for each trait are italicized and bolded.

Author Contributions: Conceptualization, J.G.R., B.S.B. and K.B.J.; methodology, J.G.R.; formal analysis, J.G.R.; writing—original draft preparation, J.G.R.; writing—review and editing, J.G.R., B.S.B. and K.B.J. All authors have read and agreed to the published version of the manuscript.

Funding: This research received no external funding.

Data Availability Statement: The data are available upon request to the corresponding author.

Conflicts of Interest: The authors declare no conflict of interest.

\section{References}

1. Van Santen, E.; Sleper, D.A. Orchardgrass. In Cool-Season Forage Grasses; Moser, L., Buxton, D., Casler, M., Eds.; ASA-CSSA-SSSA Publishers: Madison, WI, USA, 1996; pp. 503-534.

2. Jensen, K.B.; Asay, K.H.; Waldron, B.L. Dry matter production of orchardgrass and perennial ryegrass at five irrigation levels. Crop Sci. 2001, 41, 479-487. [CrossRef]

3. Jensen, K.B.; Waldron, B.L.; Asay, K.H.; Johnson, D.A.; Monaco, T.A. Forage nutritional characteristics of orchardgrass and perennial ryegrass at five irrigation levels. Agron. J. 2003, 95, 668-675. [CrossRef]

4. Papadopoulos, Y.A.; Price, M.A.; Laflamme, L.F.; Fulton, N.R.; Hunter, G.M.; Caldwell, C.D.; McRae, K.B. Differences among orchardgrass cultivars in response to hay and rotational grazing management. Can. J. Plant Sci. 1995, 75, 147-157. [CrossRef]

5. Sanderson, M.A.; Elwinger, G.F. Plant density and environment effects on orchardgrass-white clover mixtures. Crop Sci. 2002, 42, 2055-2063. [CrossRef]

6. Casler, M.D.; Fales, S.L.; McElroy, A.R.; Hall, M.H.; Hoffman, L.D.; Leath, K.T. Genetic progress from 40 years of orchardgrass breeding in North America measured under hay management. Crop Sci. 2000, 39, 1019-1025. [CrossRef]

7. Casler, M.D.; Fales, S.L.; Undersander, D.J.; McElroy, A.R. Genetic progress from 40 years of orchardgrass breeding in North America measured under management-intensive rotational grazing. Can. J. Plant Sci. 2001, 81, 713-721. [CrossRef]

8. Robins, J.G.; Bushman, B.S.; Jensen, K.B.; Blaser, G. Genetic variation for morphology and maturity among the half-sib progeny of nine orchardgrass germplasm populations. Crop Sci. 2012, 52, 2276-2282. [CrossRef]

9. Robins, J.G.; Bushman, B.S.; Jensen, K.B.; Escribano, S.; Blaser, G. Genetic variation for dry matter yield, forage quality, and seed traits among the half-sib progeny of nine orchardgrass germplasm populations. Crop Sci. 2015, 55, 275-283. [CrossRef]

10. Xie, W.; Bushman, B.S.; Ma, Y.; West, M.S.; Robins, J.G.; Michaels, L.; Jensen, K.B.; Zhang, X.; Casler, M.D.; Stratton, S.D. Genetic diversity and variation in North American orchardgrass (Dactylis glomerata L.) cultivars and breeding lines. Grassl. Sci. 2014, 60, 185-193. [CrossRef]

11. Casler, M.D.; Fales, S.L.; McElroy, A.R.; Hall, M.H.; Hoffman, L.D.; Undersander, D.J.; Leath, K.T. Half-sib family selection for forage yield in orchardgrass. Plant Breed. 2002, 121, 43-48. [CrossRef]

12. Alderson, J.; Sharp, W.C. Grass Varieties of the United States; USDA Agricultural Handbook 170; United States Department of Agriculture Soil Conservation Service: Washington, DC, USA, 2007; p. 62.

13. Riday, H.; Brummer, E.C. Heterosis in a broad range of alfalfa germplasm. Crop Sci. 2005, 45, 8-17.

14. NIRS Consortium. Available online: Nirsconsortium.com (accessed on 19 April 2021).

15. Bates, D.; Maechler, M.; Bolker, B.; Walker, S. Fitting linear mixed-effect models using lme4. J. Stat. Softw. 2015, 67, 1-48. [CrossRef]

16. R Core Team. R: A Language and Environment for Statistical Computing; R Foundation for Statistical Computing: Vienna, Austria, 2021.

17. Smith, K.F.; Casler, M.D. Spatial analysis of forage grass trials across locations, years, and harvests. Crop Sci. 2004, 44, 56-62. [CrossRef]

18. Lenth, R.V. Emmeans: Estimated Marginal Means, Aka Least-Square Means; R Package Version 1.5.5-1; 2021. Available online: https: / / cran.r-project.org/web / packages / emmeans/index.html\#: :text=emmeans $\% 3 \mathrm{~A} \% 20$ Estimated $\% 20 \mathrm{Marginal} \%$ 20Means\%2C\%20aka\%20Least \%2DSquares\%20Means\&text=Compute\%20contrasts\%20or\%20linear\%20functions,Plots \%20 and $\% 20$ other\%20displays (accessed on 28 July 2021).

19. Waldron, B.L.; Robins, J.G.; Peel, M.D.; Jensen, K.B. Predicted efficiency of spaced-plant selection to indirectly improve tall fescue sward yield and quality. Crop Sci. 2008, 48, 443-449. [CrossRef]

20. Robins, J.G.; Jensen, K.B. Genotype $\times$ environment interaction effects of propagation and defoliation on meadow bromegrass. Crop Sci. 2017, 57, 2007-2016. [CrossRef]

21. Casler, M.D.; Ramstein, G.P. Breeding for biomass yield in switchgrass using surrogate measures of yield. BioEnergy Res. 2018, 11, 1-12. [CrossRef]

22. Robins, J.G.; Jensen, K.B. Identification of creeping foxtail germplasm with high dry matter yield and nutritive value. Crop Sci. 2011, 51, 728-735. [CrossRef] 
23. United States Department of Agriculture Natural Resources Conservation Service Web Soil Survey. Available online: Websoilsurvey.nrcs.usda.gov/app (accessed on 19 April 2021).

24. Robins, J.G.; Bushman, B.S.; Jensen, K.B. Agronomic evaluation of the results of selection within late-maturing Dactylis glomerata populations. Agronomy 2021, 11, 1362. [CrossRef]

25. Horn, R.; Smucker, A. Structure formation and its consequences for gas and water transport in unsaturated arable and forest soils. Soil Till. Res. 2005, 82, 5-14. [CrossRef]

26. Barker, R.E.; Casler, M.D.; Carlson, I.T.; Berg, C.C.; Sleper, D.A.; Young, W.C. Convergent-divergent selection for seed production and forage traits in orchardgrass. II. Seed yield response in Oregon. Crop Sci. 1997, 37, 1054-1059. [CrossRef]

27. Casler, M.D.; Vogel, K.P. Accomplishments and impact from breeding for increased forage nutritive value. Crop Sci. 1999, 39, 12-20. [CrossRef]

28. Smith, K.F.; Simpson, R.J.; Oram, R.N.; Lowe, K.F.; Kelly, K.B.; Evans, P.M.; Humphreys, M.O. Seasonal variation in the herbage yield and nutritive value of perennial ryegrass (Lolium perenne L.) cultivars with high or normal herbage water-soluble carbohydrate concentrations grown in three contrasting Australian dairy environments. Aust. J. Exp. Agric. 1998, 38, 821-830. [CrossRef]

29. Ceccarelli, S. Wide adaptation: How wide? Euphytica 1989, 40, 197-205.

30. Wilkins, P.W.; Humphreys, M.O. Progress in breeding perennial forage grasses for temperate agriculture. J. Agric. Sci. 2003, 140, 129-150. [CrossRef]

31. Brummer, E.C. Capturing heterosis in forage crop cultivar development. Crop Sci. 1999, 39, 943-954. [CrossRef] 